\title{
7 RELIGIOUS PREACHING AND STATE REGULATION OF THE FREE EXERCISE OF RELIGION BY SHI'A MUSLIMS IN KADUNA STATE, NIGERIA: A CONSTITUTIONAL AND HUMAN RIGHTS DISCOURSE
}

\section{Ahmed Salisu Garba ${ }^{1}$}

\section{INTRODUCTION}

The Shi'a group otherwise called the Islamic Movement of Nigeria emerged on the Nigerian scene as the insidious effect of a combination of three things. These are the expulsion of Ibrahim Yaqoub al-Zakzaky from Ahmadu Bello University, Zaria; the influx of Islamic books from countries such as Egypt, ${ }^{2}$ Iran, Saudi Arabia and Turkey into Nigeria; and their accessibility to Ahmadu Bello University students, particularly after the Iranian revolution of 1979. ${ }^{3}$ The Shi'a began as a group in Nigeria in the early 1980s with Ibrahim Yaqoub al-Zakzaky as their leader. Al-Zazaky was a product of Muslim Student Society of Nigeria (MSSN), ${ }^{4}$ and his name came into the public domain when the management of Ahmadu Bello University, Zaria, expelled him from the university as a result of the key role he played in the popular "Islam Only" demonstration organised by the Muslim Student Society of Nigeria (MSSN) in 1977, in which the group called for the adoption of an Islamic government in Nigeria. ${ }^{5}$ His expulsion from school paved the way for him to visit Iran to explore Shi'a doctrines. ${ }^{6}$ It should be noted that before his expulsion from Ahmadu Bello University, Zaria, Zakzaky had already become radicalised and exposed to Shi'a, as a result of contacts with different Islamic writings coming into the country from radical groups in Egypt, Iran and Turkey. ${ }^{7}$ It was this scenario that provided the fertile ground for the emergence of Shi'a movement in Nigeria.

The main obsession of the group has always been protesting against what they termed the anti-Islamic posture of the Nigerian government, and at various times they called for the establishment of government similar to that of Iran in

1 The author teaches law at the Faculty of Law of the Bauchi State University, Gadau, Nigeria and is a final-year PhD Candidate at the Faculty of Law of the Bayero University, Kano in Nigeria working on the regulation of Religious Preaching in Nigeria.

2 See Hassan IH. 2015. "An Introduction to Islamic Movements and Modes of Thought in Nigeria", in Denzer L and Shereikis R (eds). PAS/ISITA Working Papers No. 1. Evanston, IL: Program of African Studies, Northwestern University, 24-26.

3 See Hassan, "An Introduction to Islamic Movements", 24-26.

4 See Hassan, "An Introduction to Islamic Movements", 24-26.

5 Hassan, "An Introduction to Islamic Movements", 24-25.

6 Hassan, "An Introduction to Islamic Movements", 24.

7 Hassan "An Introduction to Islamic Movements", 24-26. 
Nigeria. ${ }^{8}$ To achieve their aims, they adopted the well-known methodology of Taqiyya, or disguise of religious conviction. ${ }^{9}$ They maintain a strong opposition to secularism and seek to establish an Islamic government in Nigeria headed by their fellow Shi'a members. In addition, they insult and attack the first three Caliphs - Abu-Bakr, Umar and Usman - as being usurpers of the succession to Prophet Muhammad which they believe rightfully belonged to Ali. This is classical Shi'a doctrine. The Sunni Muslims that constitute the majority in Nigeria despise the Shi'a for these allegations and disrespect. Their belief, however, is that the time to take up arms is not ripe in Nigeria and nobody knows when the time will be ripe for them to take up revolutionary arms to change the government as occurred Iran.

The adoption of the taqiyya methodology has created fear in the minds of other Nigerian Muslims, on one hand, and of the Nigerian government, on the other. This is a possible explanation for why the Shi'a are always under strong suspicion by government and the people. It may also be true to say that it is this suspicion that triggers conflict between the group and government security outfits at various times. ${ }^{10}$ For example, during its silver jubilee celebration on 10 April 2005, the movement affirmed its ultimate aim to establish an Islamic government in Nigeria, but this brought them into conflict with the government. ${ }^{11}$ They also clashed with Nigerian security outfits at several times resulting in the destruction of the group's headquarters in Sokoto in July 2007 and in Zaria in 2009 and $2014 .^{12}$

Their latest clash with the security in Nigeria was on the 12 December 2015 in the city of Zaria in Kaduna State. The members of the Islamic Movement of Nigeria were doing their usual tattaki (a religious procession) in the city of Zaria, with thousands of their members out on the major streets of Zaria City. This blocked public ways and made it difficult for other road users to access the roads. Coincidentally, the Nigerian Chief of Army Staff was on his way to visit the emir of Zazzau, and he was forced to stop on the road because members of the Shi'a group blocked the way and refused the Army Chief access despite entreaties from the army officers. The logjam led to a conflict between the two groups, as a result of which many people died and the Shi'a group's

8 Hassan, "An Introduction to Islamic Movements", 25.

9 Hassan, "An Introduction to Islamic Movements", 25-26.

10 Hassan, "An Introduction to Islamic Movements", 25-26.

11 See the official website of the Islamic Movement of Nigeria (IMN) for more information on their activities, at: http://islamicmovement.org, with a Hausa version at: http://www.harkarmusulunci.org, and an Arabic version at: http:// www.alharka.net. The websites discuss such important Shi'a ideas and rituals such as Ashura, the birthday of Zahra (Maulud), idul Ghadir, and others. Furthermore, the discourses of Imam Ruhollah Moosavi Khomeini, Imam Ali Hosseini Khamenei, and other Shi'a scholars are presented on the websites, as well as Shi'ite perspectives of Sunni Islam, radicalism, terrorism, nationalism, and secularism. The websites also post material from the English-language Pointer Express and the Hausa (Mizan) news magazines of the Zakzaky group.

12 Hassan, "An Introduction to Islamic Movements", 25-26. 
headquarters at Gyellasu in Zaria City, a complex building called "Hussainiya Bakiyatullah" serving as the group's headquarters and centre of their activities, was destroyed by the Nigerian Army.

In reaction, the Kaduna State government introduced social control measures to control members of the Shi'a in the state. Firstly, the state proscribed all forms of road blockage, obstruction of public highways, and occupation of public facilities in a manner that disturbs other people in the state. It further directed people to apply and get permission before they engage in any form of procession in the state. Secondly, the state established a commission of inquiry to investigate the remote and immediate causes of the collision between the Nigeria Army and members of the Shi'a. Thirdly, the state introduced the Religious Preaching Bill, 2016, with a view to controlling religious preaching in the state. ${ }^{13}$ As a final blow in a series of measures taken prior to proposal of the Religious Preaching Bill, 2016, the state banned and declared the Islamic movement of Nigeria to be unlawful on the basis of the report of a Commission of Inquiry it set up to investigate the confrontation between the Nigeria Army and the Shi'a.

This chapter discusses these various measures, arguing that they are not reasonable in a democratic society like Nigeria and that the state in employing them is not achieving its overall aims regarding the Shi'ite population in Kaduna State. To succeed in its objectives, the state's response must be designed in accord with the Nigerian Constitution and other democratic norms of rights and freedom of religion in societies around the world. To establish this thesis, the chapter investigates the following questions: Firstly, how reasonable and justifiable are these measures in a democratic Nigeria? Secondly, what judicial review mechanism would be employed to determine their reasonability in a democracy and why? And thirdly, how do the measures accord with the freedom of religion clause in the Constitution of the Federal Republic of Nigeria?

To achieve the objectives of this chapter, I provide a detailed analysis of the proposed Religious Preaching Bill, 2016. ${ }^{14}$ First, after reviewing some literature on the regulation of religion generally to see the experience in other democracies, I examine the history of regulation of preaching in Nigeria and its effects on various religious groups. Second, I analyse the provisions of the Religious Preaching Bill, 2016 and their likely effects on religious groups in Kaduna State, particularly religious minorities. Third, I examine the particular effect of the law's ban on the Islamic Movement in Nigeria, the nation's main Shi'ite organisation, and the declaration that it was an unlawful society. The overall aim of the chapter is to recommend a theoretical framework for the purpose of ascertaining the reasonability of these religious regulation measures in a democratic Nigeria, along with a practical framework to resolve the conflict

13 The full title of the bill was "A bill for a law to substitute the Kaduna State Regulation of Religious Preaching (amendment) Edict No. 6 of 1996".

14 Kaduna State Regulation of Religious Preaching (amendment) Edict No. 6 of 1996. 
between the regulatory power of the state and the Shi'ites' freedom of religion as citizens under the Nigerian Constitution.

\section{REGULATION OF FREEDOM OF RELIGION}

Regulation of freedom of religion refers to the exercise of state regulatory power to limit citizens' rights to enjoy freedom of religion using laws that are reasonably justifiable in a democratic society generally in the interest of defence, public safety, public order, public morality, public health and in order to protect the rights and freedom of other persons. ${ }^{15}$ It is in exercise of this constitutional power that the Kaduna State government introduced the measures under scrutiny to control the Shi'a group that are the focus on of this chapter. Debates on conflicts between the regulatory power of the state and freedom of religion in democratic orders have generally been investigated from five different perspectives using a wide range of methodologies.

Firstly, American constitutional law experts Audrey Peltze ${ }^{16}$ and Kenneth Lasson ${ }^{17}$ argue that the government should regulate freedom of religion because of the perceived incivility and incitement that religious persuasion contains. Peltze's work, for example, argues that the state can restrict the right to religious preaching, so long as it is done through neutral laws that support government interests while preserving citizens' free exercise rights. How can this be achieved? And through what balancing mechanism can this achieved? These questions are largely unanswered in the theory that Peltze and Lasson describe.

Secondly, American experts on regulation of religion, such as Brian J Grim and Roger Finke, ${ }^{18}$ along with experts on religion and politics, such as Monica Duffy Toft, Daniel Philpot and Timothy Samuel Shah, ${ }^{19}$ argue that it is unreasonable and unwise to place restrictions on citizens' freedom of religion rights in a democracy, because doing so has grave consequences. These works also focus on the religious economy thesis, which posits that in a free market of ideas, religious ideas should be allowed to compete with one another in the available public space so that in the end the truth prevails. Grim and Finke's work particularly demonstrates that most restriction placed on free exercise rights in democracies are a result of collaboration between the state and dominant religious groups to suppress minority religious groups. ${ }^{20}$

15 Constitution of the Federal Republic Nigeria, 1999, sec 45(1).

16 Peltze A. 1982. "A Survey of Constitutional Challenges to Municipal Regulation of Religious Solicitation and a Suggested Legislative Compromise", Fordham Urban Law Journal 11:845.

17 Lasson K. 2005. "Incitement in the Mosques: Testing the Limits of Free Speech and Religious Liberty", Whittier Law Review 27:3-59.

18 Grim BJ and Finke R. 2011. The Price of Freedom Denied. New York: Cambridge University Press.

19 Toft MD, Philpott D and Shah TS. 2011. God's Century: Resurgent Religion and Global Politics. London: W.W. Norton \& Company.

20 Grim and Finke, The Price of Freedom Denied, 25-30. 
The suppression of minority groups is a practice which should be discouraged. There are relevant scholarly works in Nigeria to support this point. For example, Nigerian historians, Auwal Anwar and Haruna Wakili argue that dominant Islamic groups in collaboration with governments in Kaduna and Kano States acted under the pretext of control of religious preaching to repress minority Islamic groups that they regarded as dissidents. ${ }^{21}$ These works are relevant and evidence-based in support of their thesis, but none of them provide any particular balancing mechanism to test the reasonability or otherwise of laws enacted to restrict the free exercise rights of citizens in a democracy. None of them apply legal approach to study the phenomenon. Grim and Finke are engaged in empirical political science research. Toft and colleagues also write from the perspective of political science.

Thirdly, Nigeria-based legal practitioners, such as Sam Amadi and Inibehe Effiong, argue that the state should not regulate religious preaching at all despite the provision of Section 45 of the Nigerian Constitution, which clearly allows the state to derogate from such rights on the basis of defence, public order, public morality and other factors. ${ }^{22}$ Their studies were done in response to the Kaduna State's effort to amend the Kaduna State Regulation of Religious Preaching Law of 1996. ${ }^{23}$ For example, Effiong's argument, through Nigerian constitutional law, is that some specific sections of the Religious Preaching Bill, 2016 offend provisions of the Nigerian Constitution, particularly Section 10 on prohibition of the adoption of a state religion by any state in the country, Section 38 on freedom of religion, and Section 42 which allows the state to limit or derogate from these rights. Effiong does not, however, acknowledge the fact that the freedom of religion clause in the Nigerian Constitution is not an absolute right.

A fourth area of scholarship is the one that uses balancing mechanisms or proportionality tests to resolve conflicts between the regulatory power of the state and the right to religious freedom of its citizens. International agreements propose a "three-step" standard of judicial review designed to strike balance between state regulatory power and citizens' freedom of religion in a democratic society. ${ }^{24}$ The three-step balancing mechanism requires that for any limitation on freedom of religion to be legitimate in a democratic

21 Anwar AA. 1997. Gardawa, ulama and the State of Northern Nigeria: The Maitatsine phenomenon, 1962-1985, PhD Diss, University of Maiduguri. See also Wakili H. 1997. The Phenomenon of Revolts and Riots in Kano, 1983-1995: An Historical Perspective, PhD Diss, Bayero University Kano.

22 See Constitution of the Federal Republic of Nigeria 1999, sec 45(1).

23 See Effiong I. 2016. "Kaduna Preaching Bill: Resolving the Constitutional Controversy", Nigeria Today, 30 March; Amadi S. 2016. "Kaduna anti-preaching Law: A regulatory mistep" The Cable, 12 April.

24 These three standards are provided for under Article 18 (3), the provisions of the International Convention on Civil and Political Rights (ICCPR). See also European Convention on Human Rights, Article 9.2, which is similar to the provisions of the ICCPR. 
society, it must satisfy these three standards of prescribes by law requirement, furtherance of a legitimate state interest qualification and the requirement of proportionality. American constitutional law scholar Jeremy Gunn, however, questions the adequacy of the three-legged standard of review as a means for resolving conflicts between the two competing rights. His argument is that the test lacks guiding principles on the kind of evidence to admit or the question of which of the two rights is more important than the other and why and on which of the parties as between the state and the citizen the burden of proving what evidence lies and why. ${ }^{25}$ Gunn therefore recommends four standards of review instead of three. According to him, a tribunal faced with the task of interpreting derogatory clauses with respect to freedom of religion should, first, understand its role, second, properly identify the burden of proof of each of the parties, third, apply the less restrictive alternatives with correct evidentiary obligations placed on both parties, and fourthly, understand the relevant degree of scrutiny to apply. ${ }^{26}$

Gunn's argument, however, negates the role of the overall religion-state pattern, especially in a country like Nigeria, as a guiding principle in the interpretation of freedom of religion cases. This relationship is relevant when assessing the nature of the protection of freedom of religion in a country, especially since that religion is indispensable in the maintenance of public order. Particularly in the case of Nigeria, Gunn's fourth recommendation raises the question of how to determine the relevant degree of scrutiny. And this is where the main problem is. What degree of scrutiny should be applied in striking balance between state regulatory power and freedom of religion? How? Why? When?

Addressing these questions is particularly important in Nigeria. This is because the Nigerian Constitution protects a citizen's right to "freedom of thought, conscience and religion, including freedom to change his religion or belief, and freedom (either alone or in community with others, and in public or in private) to manifest and propagate his religion or belief in worship, teaching, practice and observance." 27 The Constitution also protects "freedom of expression, including freedom to hold opinions and to receive and impart ideas and information without interference" and to "assemble freely" and "associate with others." ${ }^{28}$ As law and religion scholar W Cole Durham Jr has observed, freedom of religion is a "core doctrine" amongst other fundamental human rights in the world today. ${ }^{29}$ However, the Nigerian Constitution also allows the state to derogate from these rights when "reasonably justifiable in a democratic society" on the

25 Gunn TJ. 2011. "Permissible Limitations on Freedom of Religion or Belief", in Witte J (Jr) and Green MC (eds). Religion and Human Rights: An Introduction. Oxford: Oxford University Press, 263-264.

26 Gunn, "Permissible Limitations on Freedom of Religion or Belief", 266.

27 Constitution of the Federal Republic of Nigeria, sec 38(1).

28 Constitution of the Federal Republic of Nigeria, secs 39 and 40.

29 See Durham WC (Jr). 1996. "Perspectives on religious liberty: A Comparative Framework", in Van der Vyver JD and Witte J (Jr) (eds). Religious Human Rights Global Perspective: Legal Perspectives. Boston: Martinus Nijhoff, 1-44. 
grounds of "defence, public safety, public order, public morality, public health" and for the purpose of "protecting the rights of others." 30 The Constitution, however, does not define the phrase "democratic society", the criteria for its determination, or what qualifies a law to be "reasonably justifiable" in a society such as Nigeria. The lack of definition creates a legal normative space that ought to be filled by either the court through the exercise of discretion in the event of conflict between the two competing rights, or by the legislature through the enactment of the law. A solution to this definitional dilemma requires the application of a suitable balancing mechanism or proportionality assessment technique to understand the meaning of the phrases which this works seeks to provide.

\section{THE PROPOSED PREACHING LAW IN KADUNA STATE}

In order to appreciate the controversy surrounding the proposed revision of the preaching law in Kaduna State, it is helpful to have an understanding of the pre-independence and post-independence history of religious preaching and its regulation in Northern Nigeria generally and in Kaduna State in particular. This includes effects of earlier efforts to modify the Religious Preaching Edict of 1984 through the amendment edicts of 1987 and 1996.

\section{Pre-independence period control of religious preaching in Northern Nigeria}

Regulation of Islamic religious preaching is an old phenomenon in Northern Nigeria. ${ }^{31}$ It was largely centreed in areas such as Sokoto, Zaria, Kano and Nupe land in Northern Nigeria. During this period, Kaduna was not made the capital of the northern region. The potential danger of Islamic religious preaching motivated authorities in northern Nigeria to regulate the practice. Historically, the attempt by the king of Gobir, Bawa Jan Gwarzo, in the late eighteenth century to control the Islamic religious preaching of jihadist Usman dan Fodio was the first effort to regulate Islamic religious preaching in the region. ${ }^{32}$ After the demise of King Bawa, his brother King Nafata continued along the same line but was even stricter. King Nafata restricted Islamic religious preaching in the land of Gobir ${ }^{33}$ barred people not born to Muslim families from converting to Islam $^{34}$ and ordered the converts to return to their traditional religion. ${ }^{35} \mathrm{He}$ also proscribed the wearing of turbans and veils by men and women respectively. ${ }^{36}$

30 Constitution of the Federal Republic of Nigeria, sec 45.

31 Gwandu A. 1986. "Aspects of the Administration of Justice in the Sokoto Caliphate and Shaykh Abdullahi ibn Fodio's Contribution to It", Islamic Law in Nigeria, Rashid KS (ed). Kaduna: Islamic Publications Bureau, 10-27.

32 Laremont RR. 2011. Islamic Law and Politics in Northern Nigeria. Trenton, NJ: Africa World, 64-65.

33 Laremont, Islamic Law and Politics in Northern Nigeria, 64-65.

34 Laremont, Islamic Law and Politics in Northern Nigeria, 64-65.

35 Laremont, Islamic Law and Politics in Northern Nigeria, 64-65.

36 Laremont, Islamic Law and Politics in Northern Nigeria, 64-65. 
Usman dan Fodio resisted the orders of the king, and this confrontation ended in the well-known jihad that began in $1804 .{ }^{37}$ The success of the jihad gave rise to a new administration with Usman dan Fodio as the leader. He then appointed emirs as his deputies in many parts of today's northern Nigeria, including places such as Sokoto, Zaria, Kano and Nupeland. ${ }^{38}$

The second attempt to regulate Islamic preaching took place under the colonial administration in 1926, as a reaction to incessant disagreements between the dominant Islamic religious groups in the region. These conflicts were essentially between the Qadiriyya and Tijjaniyya Sufi orders, but they also included friction associated with the emergence of new Islamic religious groups such as the Ahmadiyya and the Wahhabiyya in the region. ${ }^{39}$ At that time, moreover, the region had witnessed a rise in the presence of Christian religious missionaries, who were struggling to win more souls for Christianity, against the wishes of the northern Muslim emirs. ${ }^{40}$ As a result, the colonial government issued circulars directing resident governors of Kano, Zaria, Sokoto and Niger to issue proclamations to control religious preaching generally in their areas, in order to avoid any possible infringement of law and order. ${ }^{41}$ This was the situation up to 1950, and then through 1960 when Nigeria became independent and gained a new Constitution. That Constitution provided, for the first time, full liberal rights including freedoms of religion, expression and association. ${ }^{42}$

\section{Post-independence period control of religious preaching in Kaduna State}

The post-independence history of regulation of religious preaching started in Kaduna State, and it was probably the consequence of a form of "religious gerrymandering", a situation where the law is enacted with the aim of burdening specific religious groups. In the case of Maitatsine and Izala in the late 1970s, this practice favoured the Sufi orders, who were the dominant religious groups in the region. The premier of the Northern Region, Sir Ahmadu Bello (Sardauna of Sokoto) formed what was known as the Council of Ulama on 23 August 1963 in Kaduna State which was the capital city of Northern Nigeria.

This council was mainly composed of members of the dominant Qadiriyya and Tijaniyya Sufi groups. ${ }^{43}$ The council was to advise the northern regional

37 Laremont, Islamic Law and Politics in Northern Nigeria, 64-65.

38 Laremont, Islamic Law and Politics in Northern Nigeria, 64-80.

39 Wakili, The Phenomenon of Revolts and Riots in Kano, 38-45.

40 Afolayan F. 2009. "Religion and Politics in Colonial Nigeria: The Life and Career of Sir Walter Miller, 1782-1952", in Adekunle JL (ed). Religion in Politics: Secularism and National Integration in Modern Nigeria. Trenton, NJ: Africa World, 37-66.

41 Anwar, Gardawa, ulama and the State of Northern Nigeria, 88-90.

42 See Constitution of the Federal Republic of Nigeria, 1999, ch 4.

43 Laremont, Islamic Law and Politics in Northern Nigeria, 3. See also Umar MS. 1993. "Changing Islamic Identity in Nigeria from the 1960s to the 1980s: From Sufism to anti-Sufism", in Brenner L (ed). Muslim Identity and Social Change in Sub-Saharan Africa. Bloomington and Indianapolis: Indiana University Press, 154-178. 
government on Islamic affairs, with emphasis on disagreements among different Islamic religious groups and on grass-roots Islamic preachers in the region. ${ }^{4}$ On 7 January 1964, the youth movement Fityanul Islam, which was linked to the Tijaniyya leadership, wrote a complaint to the Sardauna against certain minority Islamic religious group whom they labelled as Gardawa (a Hausa term for graduates of Quranic schools without further Islamic training), urging him to form a committee of scholars to license the group before they were allowed to preach. They further wrote to the Council of Ulama on 25 July 1964, calling for the banning of Gardawa from religious preaching. ${ }^{45}$

In reaction, the Sardauna issued a circular to all the northern provinces, directing them to make the possession of a preaching license a precondition for Islamic religious preachers before they were allowed to preach in the region. This was a sort of "de facto" religious regulation through the indirect influence of the dominant religious groups. That measure forced the Gardawa out of the preaching scene for nearly two years and tended to favour the dominant religious groups in the religious marketplace. Although the Sardauna belonged to the Qadiriyya Islamic religious group and his actions impacted negatively on the Gardawa group, records indicate that he was fairly liberal and ecumenical in matters of religion, until he was killed in the military coup of $1966 .{ }^{46}$

It is in this context that Izala, a Wahhabi-oriented Islamic religious group which was close to anti-Sufi reformism Shaykh Abubakar Mahmud Gumi and strongly opposed to Sufi doctrines and practices, emerged on the scene in 1978. ${ }^{47}$ The emergence of Izala changed the nature of Muslim intra-religious conflict in northern Nigeria from Qadiriyya versus Tijaniyya, to a competition between Tariqa and Izala, with including both Qadiriyya and Tijaniyya groups collectively. It immediately began a campaign of offensive preaching directed against Sufi doctrines, which it labelled as bid'a (heretical innovation) and shirk (polytheism). In their preaching, Izala preachers used to mention openly the personal names of the founders of Sufi orders. They engaged in takfir and even split their mosques from those of the Sufi orders, as they did not allow their members to follow an imam affiliated to a Sufi order. This led to a series of skirmishes between the two groups. ${ }^{48}$ While the imbroglio between Izala and Tariqa groups continued, some of the disgruntled Gardawa re-emerged on the scene under the form of the Yan Tatsine in Kano State. The Yan Tatsine were the followers of Muhammadu Marwa Maitatsine, a peripatetic preacher from northern Cameroon who had settled in Kano, where he engaged in belligerent public preaching against all the existing Islamic groups in the region. ${ }^{49}$

44 Umar, "Changing Islamic Identity in Nigeria", 154-178.

45 Anwar, Gardawa, ulama and the State of Northern Nigeria.

46 Kuka MH. 2011. Religion, Power and Politics in Northern Nigeria. Ibadan: Spectrum, ix-xiii.

47 Kuka, Religion, Power and Politics in Northern Nigeria, ix-xiii.

48 Kuka, Religion, Power and Politics in Northern Nigeria, ix-xiii.

49 Kuka, Religion, Power and Politics in Northern Nigeria, ix-xiii. 
Military officers headed by Major General Muhammadu Buhari toppled the civilian administration in 1983. This regime took a cue from the past civilian administration and placed a "blanket ban on religious activities especially open-air preaching" ${ }^{50}$ In addition, it forbad the building of new mosques without the permission of emirate authorities. In order to prevent preachers from circumventing any ban imposed by the preaching board of a particular emirate by applying to a neighbouring one, the government also introduced a requirement according to which authorisation for religious preaching must be obtained both in the preacher's emirate of origin, as well as in any other emirate where he might wish to preach. Most of the preaching boards were constituted by scholars affiliated with the Sufi orders, which at the time represented most of the country's religious scholars, Izala found the new measures to be burdensome. Because of this, the founder of Izala, the late Shaykh Ismaila Idiris, was reported to have said in one of his preaching sessions, after both regimes were out of office, that "Allah will not forgive the regimes of Shagari and that of Buhari because they blocked the way of Allah." ${ }^{51}$

It was under this regime that the Regulation of Religious Preaching Edict of 1984 was first enacted.

\section{ANALYSIS OF THE RELIGIOUS PREACHING BILL, 2016}

At the time of writing this chapter, the government of Kaduna State had introduced the Religious Preaching Bill, 2016, seeking to replace the state's Regulation of Religious Preaching Edict No. 1 of 1987. This proposed law was part of the reaction of the Kaduna State government to control the Shi'ite-Army imbroglio and other similar problems in the state. My analysis of the content of the proposed law demonstrates that the proposed law is designed by the state to target the Shi'a groups.

\section{Definition of a religious preacher}

Section 3 of the proposed Religious Preaching Bill, 2016 defines a religious preacher as any person licensed by the Jama'atu Nasril Islam (JNI) or the Christian Association of Nigeria (CAN) to preach in the state. The JNI is a body established by the late premier of Northern Nigeria in the 1960s to serve as an umbrella body for all Muslims in Northern Nigeria. It has branch offices in all the states of Northern Nigeria headed by emirs or persons appointed by them. These emirs are members of the dominant Sufi dominant religious groups, either Qadriyya/Tijaniyya or Tariqa. They are also mostly Sunni Muslims and do not recognise the Shi'a as Muslims. The JNI played a role in the regulation of Islamic religious preaching in Northern Nigeria in the 1960s and 70s. For example, in 1970, when the ulama in Kano State, which consisted of members of

50 Umar, "Changing Islamic Identity in Nigeria”, 154-178.

51 Umar, "Changing Islamic Identity in Nigeria". 
the dominant Sufi orders, influenced the enactment of a law to regulate Islamic religious preaching in Kano State, the minority Gardawa groups suffered. ${ }^{52}$ They were denied preaching license to preach in the areas under the jurisdiction of Kano State, but they moved to Kaduna State and obtained preaching licenses from the JNI. ${ }^{53}$

Again, Section 3 of the proposed Religious Preaching Bill, 2016 states that any person not licensed by the JNI or the CAN may not be recognised as a religious preacher in the state. In the case of Muslims, this requirement has favoured dominant religious groups who are mostly Sunni who do not recognise Shi'a as Muslims. This is an obvious example of state favouritism extended to the dominant sects through the proposed law.

\section{Recognition of Islam and Christianity as major religions}

Section 4 of the Religious Preaching Bill, 2016 recognises Islam and Christianity as the two major religions in the state, and it establishes three committees to regulate the two religions. The law recognises the strength of Izala as an Islamic organisation in the region. In recognition of the status that the group achieved in the region in the 1970s and 1980s, the proposed Religious Preaching Bill, 2016 gives Izala equal representation with Tariqa at the Interfaith Ministerial Committee appointed by the governor. It does the same thing in terms of recognising the authority of CAN member over other Christian groups. But there are questions about into whose purview minority groups within the broader categories of Islam and Christianity fall. Christian Jehovah's Witnesses and Muslim Shi'a and Ahmadiyya are examples of these intra-religious minority groups. Section 4(2) of the Religious Preaching Bill, 2016 provides for the establishment of a ministerial committee to be composed of: (1) a chairman appointed by the governor, (2) a special adviser to the governor on internal security, (3) a senior adviser to governor on interfaith matters, (4) a member from the JNI and CAN, (5) representative of the Ministry of Justice and (6) one representative each from the Nigerian Police, Department of State Security Service, and the Civil Defense Corps. In addition, the JNI and CAN are to record of churches and mosques including data of all preachers. Minority religious groups are not contemplation as having representation or a role on the committee.

\section{JNI and CAN power over issuance of preaching licenses}

Section 5 of the Religious Preaching Bill, 2016 empowers the committees of the JNI and CAN to issue licenses to preachers for a period not exceeding one year, as approved by the ministerial committee. Although these two bodies existed

52 Kano Local Government Authority (Control of Quranic Interpretation and Admonishing) Rules 1970. This became Kano Local Government Law No. 3, 1970.

53 Anwar, Gardawa, ulama and the State of Northern Nigeria, 4. 
long before the Kaduna State government designed its preaching laws, the bodies had no power in law to issue preaching licenses in Nigeria. The JNI had done this in the past but it had no official power to do so under law. However, the preaching laws in Kaduna State had never been enforced, so there was no real way to know whether minority religious groups would have been able to preaching licenses in the state under this system. It does, however, suffice to say that the proposed law, along with the previous ones seems not to contemplate the Shi'a, Ahmadiyya and other minority religious groups as likely recipients of a preaching license.

\section{Local Government Area screening committees}

Section 6(1) of the proposed Religious Preaching Bill, 2016 establishes in each Local Government Area a committee to screen applications for licenses and recommend same to the ministerial committee. Section 6(2) provides for composition of the committee which shall consist of the following members: (1) the chairman and co-chairman each representing one of the two major religions (one Muslim and one Christian) to be appointed by the governor on the recommendation of the chairman of the Local Government Council, (2) a representative of the police, (3) two Muslims with one each representing Izala ${ }^{54}$ and Tariqa ${ }^{55}$ religious groups, and (4) two representatives of CAN.

\section{Compliance with the proposed law}

Section 7 of the bill empowers the Local Government Area committees to ensure compliance with the terms of the license so issued and register accredited preachers of all religious groups and organisations operating in the Local Government Area.

\section{Regulation of communication}

The Religious Preaching Bill, 2016 also contains a number of provisions regulating communication by religious groups. Section 9 allows all cassettes, CDs, flash drives or any other communication gadgets from accredited preachers to be played inside one's house, azure (entrance porch), church, mosque of any other designated place of worship. Section 10 provides that any cassette containing religious recording in which abusive language is used against any person or religious organisation or religious leaders past or present is prohibited in the state.

54 A Sunni Muslim group.
55 A Sufi Muslim group. 


\section{Punishment}

The proposed Religious Preaching Bill, 2016 has a section for prescribing punishments for contravention of the law. Section 12 provides that:

A person shall be guilty of an offence who in contravention of this law; (a) preaches without a valid license; (b) plays religious cassette or uses a loudspeaker for religious purpose after $8 \mathrm{pm}$ in a public place; (c) uses a loudspeaker for religious purpose other than in a mosque or church and the surrounding areas outside the stipulated prayer times; (d) uses a loudspeaker in vehicles plying the streets with religious recording; (e) abuses religious books; (f) incites disturbance of the public peace; (g) abuses or uses any derogatory term in describing any religion; or (h) carries weapons of any description whether concealed or not in places of worship or to any other place with a view to causing religious disturbance shall be guilty of an offence.

The legal implication of this section as it relates to the Shi'a and other religious groups in the state is that they may not be able to get preaching licenses, because they are not considered to be Muslims by the majority Sunni groups who control over the committees set up to enforce the proposed law. In addition, Section 13 provides, "A person who commits an offence under the provision of this law shall be liable on conviction to a term of imprisonment not exceeding two years or fine of two hundred thousand naira or both; and shall have his license revoked." Section 14 vests jurisdiction over punishment in the Sharia Courts and Customary Courts.

\section{Effects of the interim measures and the proposed preaching bill}

The first major effect of the proposed Religious Preaching Bill, 2016 involves the measures of social control introduced by the state in banning all forms of road blockages, obstruction of public highways and occupation of public facilities in a manner that causes inconvenience to other citizens in the state, and the second major effect has to do with the requirement that people seek and obtain the protection of the police before they embark on any procession in the state. These measures may look good for the maintenance of peace and order in the state, especially under Section 45 of the Nigerian Constitution, which allows the state to use its regulatory power to limit citizens' freedom of religion in the interest of defence, public safety, public order, public morality or public health or for the purpose of protecting the rights and freedoms of other persons. It should be noted that in some respects there is not much difference between the proposed Religious Preaching Bill, 2016 and the 1996 edict that it would replace. The key difference is that the 1996 edict was enacted under military rule, while the Religious Preaching Bill, 2016 has been proposed by a democratically elected government. When scrutinised in the context of democracy, measures such as the ones above may not qualify as reasonable measures in a democracy, for several reasons. 
Firstly, the interim measures taken prior to the proposal of the Religious Preaching Bill, 2016 were not prescribed by law as required in a democracy. Secondly, the measures were vague in every way and lacked procedures for religious groups to apply for permission to conduct religious activities, such as the procession or other religious gatherings that may interfere with public roads and buildings contained in the first social control measures mentioned in the beginning of this chapter. Thirdly, the measures lacked mechanisms for protecting religious groups from discrimination, especially when such groups apply to embark on their religious activities. Fourthly, the measures did not define the phrase "obstruction of public high ways" or specify who would be competent to determine it. Fifthly, the proposed Religious Preaching Bill, 2016 itself provides no information as to what would amount to inconveniencing other citizens and how to determine it, or what balancing mechanism the authorities would apply to balance the competing rights without burdening the right of the citizen or compromising the neutrality of the state. Sixthly, there is no specification of the punishment for contravention of the law. In the absence of a specified punishment, it is not constitutional to punish a citizen of Nigeria for an offence that is not written down in law under Section 36(8) of the Nigerian Constitution. Finally, it is not clear what type of evidence would be required to prove contravention of these measures in a court of law and by what means. This is especially important, because research into matters of this nature indicates that the process of exercise of discretion in different legal orders is found to be susceptible to bias, especially where it involves groups whose ideologies disagree with predominant ideologies of majority groups in the state, as in the case of the Shi'ites in both Kaduna State and Nigeria as a whole, where Sunni Muslims are the dominant group. ${ }^{56}$

\section{Ban and declaration against the Islamic Movement in Nigeria}

The Kaduna State government responded to the faceoff between Shi'a groups and the Nigerian Army in 2015 by introducing social control measures, the introduction of Religious Preaching Bill, 2016 to replace the earlier edicts and the issuance of a declaration order that baned religious preaching. The final crackdown on the Shi'ite group known as the Islamic Movement of Nigeria came on 7 October 2016, when the Kaduna State government issued an order titled the Kaduna State Official Gazette No. 21 of 7 October 2016 which banned and declared the Islamic Movement in Nigeria as an unlawful society in Kaduna State. ${ }^{57}$ The Kaduna State government relied on Section 45(1) of the Constitution of the Nigeria, which gives the state its regulatory power to restrict limit citizens freedom of religion in the interest of defence, public safety, public order, public morality or public health or for the purpose of protecting the rights and

56 See Richardson JT (ed). 2004. Regulating Religion: Case Studies from Around the Globe. New York: Kluwer Academic/Plenum, 1-15.

57 See 2016. Kaduna State Official Gazette No. 21, 7 October. 
freedoms of other persons, and Section 97(A) of the Penal Code Law, Cap 110 Laws of Kaduna State 1991, which gives the governor the power to declare as an unlawful society any organisation whose activities are dangerous to the security and good governance of the state. To justify the declaration, the government based its decision on the finding of the judicial Commission of Inquiry it set up. According to the government, the Commission of Inquiry found that the Islamic Movement in Nigeria is not a registered organisation, has a paramilitary wing and its members do not respect the laws of the country and duly constituted authorities, has overtly continued with unlawful processions, obstruction of facilities including schools without regard to the rights of other citizens and the public peace and order of the state. The governor further stated that the group's actions acts if allowed to go unchecked will constitute danger to the peace, tranquility, harmonious coexistence and governance of Kaduna State..$^{58}$

It should be noted, however, that two days after the issuance of this declaration, the governors of Kano, Plateau, Katsina and other states in Northern Nigeria issued similar declarations against the Shi' ites in their states. These declarations came with devastating consequences for the members of the Shi'a and for Nigerian democracy at large. This is because many people, including members of dominant religious groups in Kaduna, Plateau, Kano and many other states in Northern Nigeria, took the law into their hands and attacked members of the Shi'a group in various states. As a result of this violence, many were killed and their property wantonly destroyed. ${ }^{59}$

\section{TOWARD JUDICIAL REVIEW OF SECTION 45 OF THE CONSTITUTION IN NIGERIA}

The social control measures taken by the Kaduna State government were a reaction to the collision between members of the Islamic Movement of Nigeria and the Nigerian Army. These government measures have had effects on the freedom of religion of the Shi'a in Kaduna State and in Nigeria at large. These government actions and their effects have constitutional and human rights implication of regulation of religion in a democratic order like Nigeria.

As we have seen, the Constitution of the Federal Republic of Nigeria makes provision for freedom of religion. Nonetheless, these rights are not absolute. Section 45(1) of the Nigerian Constitution gives the state powers to derogate where necessary for the "defence, public safety, public order, public morality or public health; or for the purpose of protecting the rights and freedoms of other persons". This leaves plenty of room for the state to use penal laws and other legislation to restrict citizens' enjoyments of these rights.

The problem is that the Constitution does not define what a reasonably justifiable law is or the criteria for its determination in a democratic society.

58 Kaduna State Official Gazette No. 21.

59 Kaduna State Official Gazette No. 21. 
Analogously, it does not even define what a democratic society is. Herein lies the problem, since without an accurate definition, it becomes increasingly difficult to determine how one can reasonably justify the actions of a state set forth in the proposed religious preaching law, especially as regards these measures taken against the Islamic Movement in Nigeria by the Kaduna State government. Moreover, the question arises as to how the reasonability will be determined.

The absence of an appropriate definition for the phrase "reasonably justifiable law" and the criteria for its determination may be an explanation for why Nigeria has been responding to religious movements such as the Maitatsine, Darul Salam and Boko Haram with the use of force. ${ }^{60}$ Nigerian courts have not, thus far, developed any coherent standard of review that can be applied in the event of conflicts between these two competing rights. Would Nigerian courts use foreign precedents for this purpose? If the answer is yes, which country's standard of review would they choose? What criteria would they consider in making the choice? If the answer is no, what alternative interpretative technique would they apply? Will Nigeria continue to crack down on any person whose "search for separate meaning and value in life" ${ }^{16}$ differs from that of the majority established religious groups? In the process, will the Nigerian state kill innocent citizens extra judicially for holding opinions different from others?

This chapter's main focus has been not on the faceoff between the Shi'a and the Nigerian Army per se, but rather on the post-conflict measures of social control introduced by the Kaduna State government in reaction to the collision between the two groups. The measures introduced by the Kaduna State government to control the situation were designed to target the Shi'a group possibly. Even so, this chapter maintains that the Nigerian Constitution protects the right to freedom of religion of members of the Shi'a. No judicial pronouncement yet on Section 45 of the Constitution has been made, as it relates to freedom of religion. The Constitution does not define permissible derogation from freedom religion rights and the approach of the Nigerian courts in the area has created gap which should be filled to enhance societal order. What test will the Nigerian courts adopt respecting this conflict?

First, it should be pointed out that the courts in Nigeria will generally invalidate laws made contrary to the procedure laid down in the Constitution as decided in A.G. Bendel State v. A.G. Federation and Ors; ${ }^{62}$ where the legislature was found to have exceeded its powers in the making of a law, as in Lakanmi v. A.G. (West)

60 See Adekunle JO. 2009. "Government Reaction to Religious Violence", in Adenkunle JO (ed). Religion in Politics: Secularism and National Integration in Modern Nigeria. Trenton, NJ: African World Press, 329-342.

61 Reitz JC. 2005. “Freedom of Religion and Its Limitations: Judicial Standards for Deciding Particular Cases to Maintain the State's Secular Role in Protecting Society's Religious Commitments", in Ostien P et al. (eds). Comparative Perspectives on Shari'ah in Nigeria. Ibadan: Spectrum Books, 207-210. 
and $\mathrm{Ors}^{6}{ }^{63}$ where a legislation was determined to contravene fundamental human rights, as in Shugaba Darman v. Minister of Internal Affairs and Ors; ${ }^{64}$ where it was determined that exercise of powers of one organ in a manner that usurped the constitutional powers of another organ was contrary to the provisions of the Constitution, as in A.G. (Ogun) State v. A.G. Federation and Ors, ${ }^{65}$ and finally where any legislation ousts the jurisdiction of the courts, as in Ademolekun v. University of Ibadan. ${ }^{66}$ The conclusion to be drawn is that the social control measures taken with respect to the Islamic Movement of Nigeria under the proposed Religious Preaching Bill, 2016, were not backed by Nigerian constitutional law or international human right standards. The rationale for the social control measures are vague and designed to favour the dominant religious groups in the state.

Secondly, the proposed Religious Preaching Law, 2016 contains a contradiction in its very content in recognising Islam and Christianity as the only two religions in the Nigerian state. After all, the same state has banned the Shi'ites and declared them an unlawful society even though they claim to be Muslims. The law has also favoured dominant sects within the dominant religious groups in the state. In this regard, the law conferred power on the Jama'atu Nasril Islam (JNI) and the Christian Association of Nigeria (CAN) to examine aspiring religious preachers concerning their qualifications and to issue preaching licenses to those applicants found to be qualified and to that extent it is anti-religious pluralism and diversity as bedrocks of any democratic order. Conversely, the laws also criminalised preaching without a license or in contravention of the terms of the license. This raises a constitutional challenge. In a constitutional democracy where the rule of law is entrenched, the state is expected to enact laws of general application, not laws that target a specific religion or sect. ${ }^{67}$

The conclusion can that be drawn is that Sections 3, 4, 5, 6 and 7 of the proposed Religious Preaching Law, 2016 allow room for the exercise of uncontrolled discretion by men in authority, contrary to the requirement of laws in democratic legal orders. In addition, the law creates room for discrimination against minority religious groups in the state and negates the principle of religious autonomy claims in a democracy. This can be seen, especially, in the composition of the religious preaching committees where only the JNI and the CAN were recognised in the proposed law.

Another trend that can be inferred is that state regulation of religious preaching in Nigeria has been characterised by violence and discrimination against minority religious groups, which has led to incessant conflicts for years in the

63 (1971) U.I.L.R. 201.

64 (1982) 2 NCLR 459.

65 (1982) 3 NCLR 166.

66 (1968) NMLR 253.

67 Reitz, "Freedom of Religion and Its Limitations", 180. 
region. Here, the history of the proposed Kaduna State Religious Preaching Bill, 2016, intended to replace the earlier edicts is relevant. The history of the regulation of religion in Northern Nigeria indicates the influence of established religious groups in the enactment and composition of the religious preaching committees has led to injustice against minority religious groups in the state. The resort to violence by the Nigerian government as a means of social control in intervening in the clash between the two groups also indicates absence of democratic culture. It is the same trend that provided the impetus for the 2009 Boko Haram insurgency in Nigeria. Nigeria cannot afford to continue with the current extra-judicial means of resolving conflicts between two constitutional rights.

A final conclusion that can be drawn is that the proposed Kaduna State Religious Preaching Law, 2016 gave the local authorities power without defining its scope in the discharge of their function. The consequence of this was arbitrariness, abuse and violation of the right to freedom of religion of the citizens. It may thus be difficult to secure true religious pluralism, which is an inherent feature of the notion of a democratic society, under the present provisions of the proposed Religious Preaching Bill, 2016. It is valid therefore to conclude that these measures need to be redesigned to agree with free exercise norms in democratic orders in order to qualify as reasonable in a democratic Nigeria. Finally, to be able to determine their reasonability, an appropriate balancing mechanism based on Nigeria's religion-state relations should be applied in resolving conflict between the two rights.

\section{CONCLUSION}

The analysis in this chapter calls for a recommendation of a balancing mechanism based on Nigeria's religion-state relations and local experience that may be useful to courts and legislators in handling conflicts between the two competing rights in Nigeria. This balancing mechanism calls for attention to the principle of substantive due process, the existing religion-state pattern and the local experience of countries to the existing criteria used as standards of review in the resolution of conflicts between the two rival constitutional rights. The reassertive nature of the role of religion in the public domain in Nigeria and the world at large indicates that religion must be involved in the maintenance of public order and security at the global level. ${ }^{68}$ Therefore in the event of conflict between these competing rights in the modern world today, this balancing mechanism that is the most appropriate is the one that recognises the current role of religion, the local experience of countries and the need to do justice through the application of the principle of procedural due process.

Part of the local experience of Nigeria for the past twenty years has been managing crises related to religion. Government restriction of the free exercise rights of some religious groups in favour of dominant religious groups in some

68 See Toft MD et al., God's Century: Resurgent Religion and Global Politics, 207-223. 
states of northern Nigeria has contributed to the crises. Neither the government nor any of the victims has approached the court for judicial determination of the conflict. Even if they had approached the courts, only God knows what would have happened considering the mindset of the judges and generally the people of Nigeria on minority religious groups and their ideologies, especially Shi'a group. Another challenge for Nigeria is whether in the light of the present experience surrounding the proposed Kaduna State Religious Preaching Bill, 2016, which seeks to substitute the state's Regulation of Religious Preaching Law of 1996, the Nigerian Shi'a movement and the military clash that resulted, the government will allow members of religious groups full self-determination and right to freely practice religion. Whatever may be the case and as far as democracy is concerned, governments in democracies anywhere in the world have no right to determine to anybody or group of persons what to believe and what not to believe. 